\title{
Pertumbuhan Enterococcus faecalis ID 6017 dan Kemampuan Dekolorisasi Beberapa Konsentrasi Orange II dalam Sistem Sinambung
}

\author{
The Growth of Enterococcus faecalis ID 6017 and Its Ability to Decolorize Several \\ Concentrations of Orange II in Continues System
}

\author{
Patrisia Ilene Kara, V. Irene Meitiniarti*, K.H. Timotius \\ Fakultas Biologi Universitas Kristen Satya Wacana, Salatiga \\ E-mail: irene_meiti@yahoo.com*Penulis untuk korespondensi
}

\begin{abstract}
Orange II is the most used colorant in industries which involve coloring process. So far, Orange II decolorization process by Enterococcus faecalis ID 6017 under batch system has been proven to be able to decolorize orange to colourless. In the presence of intermediates accumulation in batch system, claimed bioprocess development with continues system. An hypothesis was carried out that continues system could reduce intermediates generated by Orange II degradation. This research aimed to know the growth of Enterococcus faecalis and its Orange II decolorization ability in the medium supplemented with Orange II with different concentration under continues system. The research was set on continues system with single cultures Enterococcus faecalis, grown in medium with 80, 120, or 160 mg/L Orange II concentration. Measured parameters were Orange II concentration, biomass, glucose concentration, intermediates compound (sulphanilic acid). It could be concluded that under continues system $(D=0.06$ hour $^{-1}$ ), Enterococcus faecalis could decolorize Orange II until 160 mg/l.
\end{abstract}

Key words: Orange II, decolorization, E. faecalis ID6017, continues system

Diterima: 09 Juli 2007, disetujui: 24 Januari 2008

\section{Pendahuluan}

Pewarna azo merupakan golongan pewarna sintetik yang paling banyak digunakan dalam berbagai industri yang melibatkan proses pewarnaan. Selama proses pewarnaan berlangsung, secara keseluruhan paling sedikit 4\% pewarna terbuang bersama air limbah industri (Ollgaard et al., 1999 dalam Coughlin et al., 2003). Penggunaan pewarna azo oleh industri dilaporkan sekitar $60-70 \%$ dari total 10.000 pewarna yang umumnya digunakan oleh industri tekstil (Carliel et al., 1995 dalam Mendez et al., 2004).

Munculnya pewarna azo dalam dunia industri menimbulkan masalah ketika jenis pewarna ini sulit terurai secara alami. Masalah lingkungan yang ditimbulkan antara lain, seperti buangan limbah cair industri yang dapat berpengaruh pada kualitas air dan dapat menjadi ancaman bagi publik mengingat pewarna azo dan hasil metabolitnya toksik dan berpotensi karsinogenik (Chung et al., 1981).

Salah satu jenis pewarna azo yang paling sering digunakan adalah Orange II atau dengan nama kimia Acid Orange 7. Orange II merupakan salah satu pewarna azo yang termasuk monoazo dengan kromofor berupa ikatan azo $(-\mathrm{N}=\mathrm{N})$. Adapun rumus kimia Orange II adalah p-(2-Hydroxy-1-naphthylazo) benzenesulfonic acid sodium salt, dengan rumus molekul $\mathrm{C}_{16} \mathrm{H}_{11} \mathrm{~N}_{2} \mathrm{NaO}_{4} \mathrm{~S} .5 \mathrm{H}_{2} 0$ (Anonim, 1968).

Proses degradasi pewarna azo, termasuk Orange II dapat terjadi secara kimiawi, fisikawi, dan biologis. Cara fisikawi, misalnya 
flokulasi, filtrasi membran, sedangkan cara kimiawi misalnya oksidasi, penambahan senyawa kimia tertentu yang mampu mendorong pemecahan ikatan azo, dan lain lain. Kedua metode di atas kurang efektif diterapkan karena beberapa kelemahan seperti input energi yang besar, biaya operasional yang tinggi, dan adanya senyawa kimia toksik yang dihasilkan (Knapp et al., 2001).

Metode biologis atau biodegradasi umumnya melibatkan mikroorganisme, seperti pemanfaatan bakteri yang mampu mengubah senyawa beracun menjadi senyawa tak beracun. Beberapa penelitian berhasil menemukan adanya bakteri yang mampu mendegradasi pewarna azo, umumnya bakteri ini tergolong bakteri yang hidup dalam usus (intestinum) (Chung et al., 1978). Salah satu jenis bakteri yang mampu melakukan reduksi pewarna azo adalah Enterococcus faecalis (Meitiniarti et al., 2004; Meitiniarti et al., 2005). Menurut Meitiniarti et al., (2006), Enterococcus faecalis mampu tumbuh dan mendekolorisasi Orange II pada medium semisintetik yang mengandung Orange II hingga $120 \mathrm{mg} / \mathrm{L}$ secara curah sulang.

Proses degradasi pewarna azo dimulai dengan putusnya ikatan azo yang berperan sebagai kromofor dalam kondisi anaerob (Gottlieb et al., 2002). Putusnya ikatan azo ini akan menyebabkan hilangnya warna atau dikenal dengan istilah dekolorisasi. Dekolorisasi ini merupakan tahap awal dalam degradasi pewarna azo oleh mikroorganisme.
Pemutusan ikatan azo pada Orange II terjadi secara enzimatis dengan peran enzim azoreduktase dan akan menghasilkan asam sulfanilik (4-aminobenzenesulfonic acid) dan 1amino-2-napthol (Gambar 1). Proses pemutusan ikatan azo pada Orange II terjadi optimum pada $\mathrm{pH}$ antara 5 - 8 dan pada suhu sekitar $30^{\circ} \mathrm{C}$ (Williamson, 1989; Zimmermann et al., 1982).

Proses dekolorisasi Orange II ini memerlukan kosubstrat yang berperan sebagai donor elektron (Carliel et al., 1995 dalam Mendez-Paz et al., 2003). Kosubstrat yang baik untuk mendapatkan tingkat dekolorisasi pewarna azo yang tinggi adalah glukosa (Wuhrman et al., 1980; Haug et al., 1991). Dalam mendekolorisasi pewarna azo, secara umum mikroorganisme yang berperan dalam reduksi warna dipengaruhi beberapa faktor, antara lain: konsentrasi pewarna, konsentrasi substrat, komposisi medium, dan $\mathrm{pH}$ (Chang et al., 2001; Knapp et al., 2001).

Selama ini, penelitian tentang dekolorisasi Orange II oleh Enterococcus faecalis dilakukan dengan sistem batch. Penggunaan sistem batch telah membuktikan terjadinya penguraian warna atau dekolorisasi Orange II oleh Enterococcus faecalis, tetapi sistem ini mempunyai kelemahan, yakni terjadinya akumulasi senyawa antara reaktor. Senyawa antara ini dapat bersifat toksik terhadap mikroba pengurai warna tersebut yang dapat mengakibatkan penurunan aktivitas mikroba dalam reaktor.

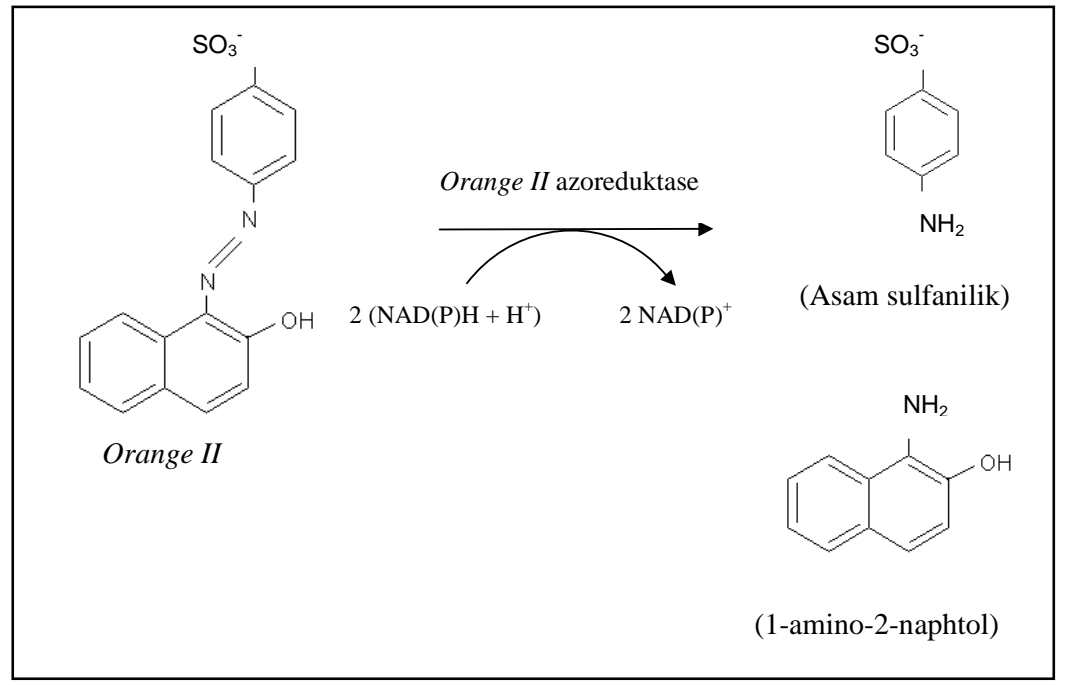

Gambar 1. Reduksi Acid Orange 7 (Zimmermann et al., 1982) 
Adanya kendala seperti ini menuntut pengembangan proses. Pengembangan bioproses yang dapat dirancang untuk optimasi dekolorisasi adalah sistem kontinyu atau sinambung. Sistem sinambung merupakan sistem terbuka, yakni sistem pengaliran sejumlah volum yang tetap dengan penambahan medium segar secara kontinyu dan sebagian dari medium dan sel serta produk dikeluarkan (sebagai effluent) dari reaktor dengan laju yang konstan. Suatu waktu tertentu pada sistem sinambung akan mencapai kesetimbangan, yakni jumlah sel dan status nutrien di dalam reaktor akan menjadi konstan dan sistem ini dikatakan pada kondisi tunak (steady state).

Proses dekolorisasi Orange II dengan sistem sinambung ini dirancang menggunakan beberapa konsentrasi Orange II untuk mengetahui pertumbuhan dan kemampuan reduksi warna Orange II oleh Enterococcus faecalis. Konsentrasi pewarna yang ditambahkan sangat berpengaruh terhadap pertumbuhan dan kemampuan mikroba dalam melakukan dekolorisasi. Menurut Pearce et al., (2003), semakin rendah konsentrasi pewarna yang ditambahkan ke dalam medium akan semakin cepat pula dekolorisasi. Sebaliknya, semakin besar konsentrasi pewarna, waktu yang dibutuhkan untuk melakukan dekolorisasi pun semakin lama.

\section{Metode Penelitian}

\section{Bahan}

Kultur murni Enterococcus faecalis ID 6017 diperoleh dari Laboratorium Mikrobiologi, Fakultas Biologi, Universitas Kristen Satya Wacana, Salatiga. Medium pemeliharaan yang digunakan adalah Tryptone Soy Agar (TSA). Medium pertumbuhan yang digunakan adalah medium semisintetik $\mathrm{MgSO}_{4} .7 \mathrm{H}_{2} \mathrm{O}$ 0,25; $\left(\mathrm{NH}_{4}\right)_{2} \mathrm{SO}_{4} 1,98 ; \mathrm{K}_{2} \mathrm{HPO}_{4}$ 7,095; $\mathrm{KH}_{2} \mathrm{PO}_{4} 3,574$; Glukosa 0,9 dan Ekstrak Khamir 0,25. Pewarna Orange II atau Acid Orange 7 Merck C. I. 15510 diperoleh dari Sigma.

\section{Preparasi inokulum}

Kultur murni Enterococcus faecalis ID 6017 pada Tryptone Soy Agar (TSA) miring usia 24 jam diinokulasikan pada $500 \mathrm{~mL}$ medium semisintetik tanpa pewarna dan diinkubasikan pada shaker dengan kecepatan 120 - 150 rpm. Prekultur diinkubasi sampai kerapatan optis 0,3 - 0,4 pada panjang gelombang $500 \mathrm{~nm}$ (OD 500 ) dan digunakan sebagai inokulum.

\section{Uji kemampuan dekolorisasi Orange II secara sinambung}

Sebanyak $500 \mathrm{~mL}$ prekultur dituang secara aseptis ke dalam fermentor, selanjutnya dibuat rangkaian set sistem sinambung. Medium sintetik yang mengandung pewarna Orange II (80 mg/L, 120 mg/L, dan $160 \mathrm{mg} / \mathrm{L}$ ) dialirkan dengan kecepatan alir $60 \mathrm{ml}$ setiap jam dan diinkubasi sampai terjadi dekolorisasi. Setelah volume reaktor mencapai $1 \mathrm{~L}$, maka mulai dilakukan pengambilan sampel efluen.

\section{Metode sampling dan analisis sampel}

Pengambilan sampel dilakukan setiap 12 jam hingga kondisi mencapai steady state yang ditandai dengan konsentrasi biomassa yang mulai tetap. Parameter yang diukur meliputi konsentrasi Orange II, berat kering sel, konsentrasi glukosa, konsentrasi senyawa antara (asam sulfanilat).

Konsentrasi Orange II diukur secara spektrofotometrik pada panjang gelombang 482 nm (Zimmermann et al., 1982). Analisis konsentrasi glukosa dilakukan dengan menggunakan metode kolorimetri (DNSA) (James, 1995). Pengukuran berat kering sel dilakukan secara tidak langsung dengan metode turbidimetri (Koch, 1981). Konsentrasi asam sulfanilat diukur secara spektrofotometrik pada panjang gelombang $295 \mathrm{~nm}$ (Modifikasi dari Perei et al., 2000; Pinheiro et al., 2003).

Hasil analisis digunakan untuk menentukan produksi biomassa, produksi asam sulfanilat, reduksi Orange II, dan konsumsi glukosa, sehingga dapat digunakan untuk mengetahui pertumbuhan Enterococcus faecalis ID 6017 dan kemampuan dekolorisasinya dalam medium yang mengandung beberapa konsentrasi Orange II dengan sinambung. 


\section{Hasil dan Pembahasan}

Penelitian yang dilakukan telah membuktikan bahwa Enterococcus faecalis ID 6017 mampu tumbuh dan melakukan dekolorisasi dalam medium semisintetik sampai dengan konsentrasi Orange II 160 mg/L pada sistem sinambung dengan kecepatan pengenceran yang tetap (D) 0,06 jam ${ }^{-1}$. Hasil pengukuran dan penghitungan beberapa parameter pertumbuhan Enterococcus faecalis ID 6017 tercantum pada Tabel 1.

Secara keseluruhan, hasil penelitian menunjukkan bahwa terjadi dekolorisasi Orange II dan konsumsi glukosa yang diikuti dengan kenaikan biomassa. Hal ini menunjukkan bahwa Enterococcus faecalis memanfaatkan glukosa untuk pertumbuhan melalui pembentukan biomassa. Schlegel (1994) menyatakan bahwa glukosa dikonsumsi oleh sel sehingga menghasilkan ATP yang kemudian dimanfaatkan untuk pertumbuhan dan pemeliharaan sel.

Dalam proses reduksi warna Orange II, glukosa yang dikonsumsi diduga juga digunakan untuk aktivitas dekolorisasi. Ada beberapa penelitian yang mendukung hipotesis ini, seperti Kapdan et al., (1999) yang menyatakan bahwa glukosa merupakan sumber karbon yang baik untuk mendapatkan tingkat dekolorisasi Everzol Turquoise Blue G oleh C. versicolor MUCL yang tinggi, dibandingkan dengan pati, molase, dan fruktosa. Russ et al., (2000) juga menambahkan bahwa glukosa mampu memacu aktivitas enzimatis (azoreduktase) untuk memutus ikatan kromofor pada Orange II, yaitu dengan memanfaatkan hasil katabolisme glukosa berupa NADH sebagai redox mediator.

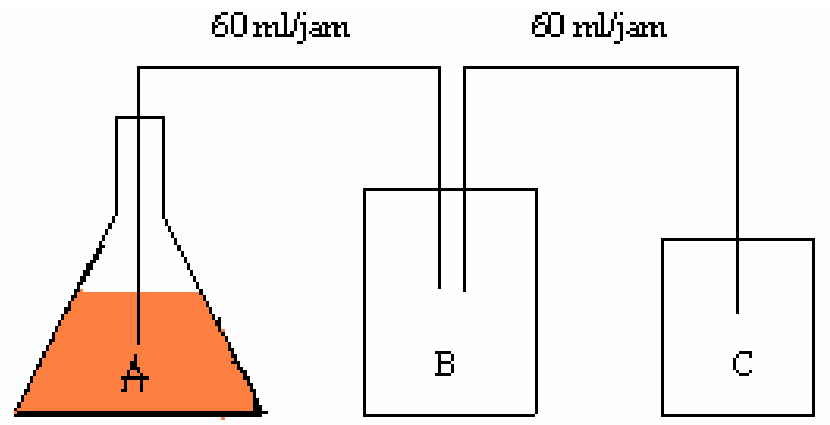

Gambar 2. Skema Setting Fermentor Secara Sinambung Keterangan: $\mathrm{A}=$ Medium sintetik yang mengandung pewarna Orange II $\mathrm{B}=$ Reaktor (fermentor) yang berisi prekultur sebanyak $500 \mathrm{ml}$ $\mathrm{C}=$ Tempat efluen

Tabel 1. Pertumbuhan dan dekolorisasi Orange II dengan sistem sinambung $\left(\mathrm{D}=0.06 \mathrm{~L}\right.$ jam $\left.{ }^{-1}\right)$ oleh Enterococcus faecalis

\begin{tabular}{lcccc}
\hline \multirow{2}{*}{\multicolumn{1}{c}{ Parameter }} & \multirow{2}{*}{ Unit } & \multicolumn{3}{c}{ Konsentrasi Orange II (mg/L) } \\
\cline { 3 - 5 } & & $\mathbf{8 0}$ & $\mathbf{1 2 0}$ & $\mathbf{1 6 0}$ \\
\hline \hline Orange II terdekolorisasi & $\mathrm{mg} / \mathrm{l}$ & 76.89 & 116.27 & 139.49 \\
Efektivitas dekolorisasi & $\%$ & 96 & 97 & 87 \\
Produksi biomassa & $\mathrm{mg} / \mathrm{l}$ & 101.43 & 166.07 & 169.94 \\
Konsumsi glukosa & $\mathrm{mg} / \mathrm{l}$ & 920.37 & 771.33 & 602.56 \\
Produksi asam sulfanilat & $\mathrm{mg} / \mathrm{l}$ & 0.09 & 0.07 & 0.04 \\
\hline \hline
\end{tabular}


Walaupun glukosa digunakan untuk pertumbuhan dan aktivitas dekolorisasi, tetapi data konsumsi glukosa konsentrasi Orange II $160 \mathrm{mg} / \mathrm{L}$ justru lebih rendah dari pada konsentrasi Orange II 120 mg/L (Tabel 1). Hal ini berbeda dengan dugaan awal bahwa pada konsentrasi Orange II yang lebih tinggi, konsumsi glukosa tentu lebih tinggi, terlebih dengan produksi biomassa yang sedikit lebih tinggi. Lebih rendahnya konsumsi glukosa pada konsentrasi Orange II $160 \mathrm{mg} / \mathrm{l}$ ini diduga karena pengaruh kondisi lingkungan dalam medium yang berubah akibat makin tingginya konsentrasi Orange II dan dihasilkannya senyawa antara hasil dekolorisasi yang lebih banyak. Seperti diketahui proses degradasi Acid Orange 7 dalam kondisi anaerob akan menghasilkan asam sulfanilat dan 1 amino 2 naftol sebagai senyawa antara. Senyawa antara ini cenderung bersifat toksik dan sulit didegradasi sehingga dapat terakumulasi dalam medium. Mendez-Paz et al., (2004) dalam penelitiannya menyatakan bahwa asam sulfanilat yang dihasilkan dari reduksi warna Orange II secara anaerob cenderung terakumulasi di dalam medium.

Namun terdapat pula beberapa mikroorganisme yang mampu memanfaatkan senyawa antara hasil dekolorisasi sebagai sumber karbon, energi, dan nitrogen, seperti Sphingomonas sp yang memanfaatkan 1 amino 2 naftol (Coughlin et al., 2003), dan Pseudomonas palleronii serta Agrobacterium radiobacter yang mampu mengkonsumsi asam sulfanilat sebagai sumber karbon, energi, nitrogen, dan sulfur (Feigel dan Knackmuss, 1992). Fenomena ini memunculkan dugaan lain yakni ada dugaan terjadinya perubahan mekanisme intraseluler pada $E$. faecalis akibat kondisi lingkungan yang berubah, sehingga mampu memanfaatkan senyawa intermediet ini sebagai substrat. Dugaan ini diperkuat dengan terjadinya peningkatan biomassa pada konsentrasi $160 \mathrm{mg} / \mathrm{L}$ dan menurunnya konsentrasi asam sulfanilat pada konsentrasi Orange II 160 mg/l (Tabel 1).

Aktivitas dekolorisasi pada konsentrasi Orange II $160 \mathrm{mg} / \mathrm{L}$ lebih tinggi dibanding konsentrasi Orange II 80 dan 120 mg/L (Tabel 2). Lebih tingginya aktivitas dekolorisasi yang ditunjukkan dari jumlah Orange II yang terdekolorisasi pada konsentarsi Orange II 160 $\mathrm{mg} / \mathrm{l}$ ini diduga juga disebabkan adanya senyawa antara, yaitu 1 amino 2 naftol yang dapat berperan sebagai redox mediator. Adanya senyawa antara sebagai redox mediator diduga menginduksi mekanisme autokatalisis dalam degradasi Orange II. Mekanisme autokatalisis itu mungkin terjadi ketika kadar senyawa antara dalam medium relatif tinggi dan mencapai batas tertinggi yang dapat ditoleransi oleh $E$. faecalis, berarti senyawa antara tersebut tidak diteruskan untuk didegradasi lebih lanjut. Hal ini menyebabkan senyawa antara akan menginduksi balik pada proses dekolorisasi dan membantu meningkatkan proses penghilangan warna. Van der Zee et al., (2000) menyatakan bahwa senyawa antara, terutama 1 amino 2 naftol sebagai hasil reduksi warna dapat berperan sebagai redox mediator yang membantu meningkatkan reduksi warna Acid Orange 7. Pearce et al., (2003) juga menyatakan bahwa adanya redox mediator dapat membantu penghilangan warna pada sistem pengolahan air limbah yang mengandung pewarna.

Bila dilihat nilai efektivitas dekolorisasi, dapat dilihat bahwa dari konsentrasi Orange II 80 sampai $120 \mathrm{mg} / \mathrm{l}$ nilai efektivitas dekolorisasi menunjukkan peningkatan. Pada konsentrasi $160 \mathrm{mg} / \mathrm{l}$, efektivitas dekolorisasi mengalami penurunan menjadi 87\% (Tabel 1). Hal ini mungkin disebabkan oleh menurunnya kemampuan dekolorisasi bakteri karena bakteri harus langsung beradaptasi dengan konsentrasi Orange II 160 mg/l. Bakteri dalam keadaan ini lebih sulit melakukan dekolorisasi, selain karena tingginya konsentrasi Orange II, juga karena lingkungan tempat hidup bakteri tersebut lebih ekstrim, sehingga bakteri tidak hanya memanfaatkan energi yang diperolehnya untuk melakukan dekolorisasi, melainkan juga untuk pertumbuhan dan pertahanan diri.

Tingginya aktivitas dekolorisasi yang terjadi juga diikuti peningkatan biomassa, sehingga ada asumsi bahwa peningkatan konsentrasi pewarna Orange II dapat meningkatkan penambahan biomassa. Penambahan biomassa hanya meningkat terutama sampai konsentrasi $120 \mathrm{mg} / \mathrm{l}$, lebih dari $120 \mathrm{mg} / \mathrm{l}$ penambahan biomassanya tidak terpaut jauh. Hal ini menunjukkan bahwa pada 
konsentrasi $160 \mathrm{mg} / \mathrm{L}$, pertumbuhan E. faecalis sudah mencapai batas toleransi untuk beradaptasi terhadap tingginya konsentrasi Orange II.

Jika dibanding dengan pertumbuhan $E$. faecalis pada medium yang mengandung Orange II $120 \mathrm{mg} / \mathrm{L}$ dengan sistem curah dan curah sulang (Meitiniarti et al., 2006), tampak bahwa dengan sistem pertumbuhan sinambung terjadi produksi biomassa dan jumlah Orange II terdekolorisasi yang lebih banyak. Pada sistem curah dan curah sulang dengan konsentrasi Orange II $120 \mathrm{mg} / \mathrm{l}$, dihasilkan biomassa dan Orange II terdekolorisasi berturut-turut sebanyak 50,4 dan $93 \mathrm{mg}$ biomassa kering, dan 64,09 dan 114,82 mg Orange II. Padahal konsumsi glukosa pada sistem curah sulang dan sinambung tidak jauh berbeda, yaitu berturut-turut sebesar 4,27 dan 4,28 mM. Kenyataan ini menunjukkan bahwa sistem sinambung cocok untuk diterapkan dalam pengolahan limbah yang mengandung pewarna karena dapat mereduksi pewarna Orange II dengan konsentrasi yang cukup tinggi dan produksi biomassa yang tinggi. Namun perlu diperhatikan pula adanya sisa glukosa dan senyawa intermediet yang tidak digunakan dan terbuang bersama aliran keluar sistem (efluen). Kandungan bahan-bahan organik dalam efluen ini masih perlu diolah secara aerobik.

\section{Kesimpulan dan Saran}

\section{Kesimpulan}

Pada sistem sinambung $\left(D=0.06 \mathrm{jam}^{-1}\right)$, Enterococcus faecalis mampu melakukan dekolorisasi Orange II walaupun konsentrasi Orange II yang cukup tinggi, dalam hal ini 160 mg/l. Penambahannya pada konsentrasi yang lebih tinggi cenderung lebih baik.

\section{Saran}

Dalam penelitian ini, buangan sistem (efluen) masih mengandung cukup banyak glukosa dan senyawa antara, sehingga masih diperlukan penelitian konsentrasi glukosa yang dapat dimanfaatkan secara efisien dalam sistem sinambung dan pemanfaatan senyawa antara yang terbentuk.

\section{Daftar Pustaka}

Anonim. 1968. The Merck Index: An Encyclopedia of Chemical and Drugs. $8^{\text {th }}$ Ed. Merck and Co., Inc. New Jersey.

Chang, J.S., Chou, C., Lin, Y.C., Lin, P.J., Ho, J.Y. and $\mathrm{Hu}$, T.L. 2001. Kinetic Characteristic of Bacterial Azo-Dye Decolorization by Pseudomonas luteola. Water Research. 35 (12): 2841-2850.

Chung, K.T., Fulk, G.E. and Andrews, A.W. 1978. Reduction of Azo Dyes by Intestinal Anaerobes. Appl. and Enviro. Microbiol. 35: 558-562.

Chung, K.T., Fulk, G.E. and Andrews, A.W. 1981. Mutagenicity Testing of Some Commonly Used Dyes. Appl. and Enviro. Microbiol. 42 (4): 641-648.

Coughlin, M.F., Kinkle, B.K. and Bishop, P.L. 2003. High Performance Degradationof Azo Dye Acid Orange 7 and Sulfanilic Acid in a Laboratory Scale Reactor After Seeding with Cultured Bacterial Strains. Water Research (37): 2757-2763.

Feigel, B.J. and Knackmuss, H.J. 1992. Syntrophic Interactions During Degradation of 4Aminobenzenesulfonic Acid by a Two Species Bacterial Culture. Archives of Microbiol. 159: 124-130.

Gottlieb, A., Saw, C., Smith, A., Wheatley, A. and Forsythe, S. 2002. The Toxicity of Textile Reactive Azo Dyes After Hydrolysis and Decolourisation. J. of Biotech.101: 49-56.

Haug, W., Schmidt, A., Nortemam, B., Hempel, D.C., Stolz, A. and Kanckmuss, H.J. 1991. Mineralization of The Sulphonated Azo Dyes Mordant Yellow 30 by a 6aminonapthalene2-benzenesulfonate-Degrading Bacterial Consortium. Appl. and Enviro. Microbiol. (57): 3144-9.

James, C.S. 1995. Analytical Chemistry of Foods. Blackie Academic and Professional. London.

Kapdan, I.K., Tekol, M. and Sengul, F. 1999. Effects of Environmental Conditions on Biological Decolorization of Textile Dyestuff by $C$. versicolor. Enzyme and Microbial Technology. 26: 381-387.

Kapdan, I.K., Tekol, M. and Sengul, F. 2003. Decolorization of Simulated Textile Wastewater In An Anaerobic-Aerobic Sequential Treatment System. Enzyme and Microbial Technology. 33: 231-235. 
Knapp, J.S., Vantoch-wood, E. and Zhang, F. 2001. Use of Wood-Rotting Fungi for The Decolorization of Dyes and Industrial Effluents. In: Gadd, G.M. (Eds.). Fungi in Bioremediation. pp. 242-304, United Kingdom: Cambridge University Press.

Koch, A.L. 1981. Growth Measurement. In: Gerhardt, P., Murray, R.G.E., Costilow, R.N., Nester, E.W., Wood, W.A., Krieg, N.R., Phillips, G.B. (Eds.). Manual of Methods for General Bacteriology. Washington DC: American Society for Microbiology.

Meitiniarti, V.I., Napitupulu, M.M. dan Timotius, K.H. 2004. Pertumbuhan curah Enterococcus faecalis ID6017 dan kemampuan dekolorisasi Reactive Red-2 pada medium yang mengandung gliserol. Biota IX (1): 19-24.

Meitiniarti, V.I., Sutarto, E.S., Timotius, K.H. dan Hendrawan, J.T. 2005. Dekolorisasi Pewarna Azo Orange II oleh Enterococcus faecalis ID6017 dan Chryseobacterium indologenes ID 6016. Berkala Ilmiah Biologi 4 (5): 303313.

Meitiniarti, V.I., Vandiyani, S.E. dan Timotius, K.H. 2006. Pengaruh Penyulangan Medium yang Mengandung Orange II terhadap Pertumbuhan Enterococcus faecalis ID 6017 dan Kemampuan Dekolorisasinya. Biota XI (1): 52-58.

Mendéz-Paz, Omil, F. and Lema, J.M. 2003. Modeling of The Acid Orange 7 Anaerobic Biodegradation. Water Science and Technology. 48 (6): 133-139.

Mendéz-Paz, Omil, F. and Lema, J.M. 2004. Anaerobic Treatment of Azo Dye Acid Orange 7 Under Fed-batch and Continuous Conditions. Water Research. 39: 771-778.

Pearce, C.I., Lloyd, J.R. and Guthrie, J.T. 2003. The Removal of Colour from Textile Wastewater Using Whole Bacterial Cells; A Review. Dyes and Pigments. 58: 179-196.
Perei, K., Rakhely, G., Kiss, I., Polyal, B. and Kovacs, K.L. 2000. Biodegradation of Sulphanilic Acid by Pseudomonas paucimobilis. Appl. Microbial. Biotech. 55: 101-107.

Pinheiro, H.M., Touraud, E. and Thomas, O. 2003. Aromatic Amines from Azo Dye Reduction: Status Review With Emphasis On direct UV Spectrophotometric Detection In Textile Industry Wastewaters. Dyes and Pigment. 61: 121-139.

Russ, R., Rau, J. and Stolz, A. 2000. The Function of cytoplasmic flavin reductases in the Reduction of Azo Dyes by Bacteria. Appl. and Enviro. Microbiol. 66 (4): 1429-1434.

Schlegel, H.G. 1994. Mikrobiologi Umum (Penerjemah Tedjo Baskoro, R.M.; Penyunting Wattimena, J.R.). Edisi ke-6. Yogyakarta: Gadjah Mada University Press.

Van der Zee, F.P., Lettinga, G. and Field, J.A. 2000. The Role of Autocatalysis in The Mechanism of An Anaerobic Azo Reduction. Water Science Technology. 42 (5-6): 301-8.

Williamson, K.L. 1989. Macroscale and Microscale Organic Experiments. Toronto: D.C. Health and Company.

Wuhrmann, K., Mechsner, K.I. and Kappeler, T.H. 1980. Investigation on Rate Determining Factors In The Microbial Reduction of Azo Dyes. European J. of Appl. Microbial Biotech. (9): 228-325.

Zimmermann, T., Kulla, H.G. and Leisinger, T. 1982. Properties of Purified Orange II Azoreductase, the Enzyme Initiating Azo Dye Degradation by Pseudomonas KF46. European J. of Biochem. 129: 197-203. 